\title{
MASYARAKAT SIPIL MALAYSIA: MOMENTUM DAN KEMUNCULANNYA
}

\author{
Dori Efendi \\ Haryadi \\ Universiti Putra Malaysia (UPM), Serdang, Malaysia \\ Jalan UPM, 43400 Serdang, Selangor, Malaysia \\ Email: doriefendi@yahoo.com
}

\begin{abstract}
This article discussed about civil society movement in Malaysia. There are two causes that make this discussion became important. First, civil society was born because it demanded a political change direct to fair openness and become the foundation for protest to the goverment. Based on this explanation, question emerged. What does civil society mean? And how it emerges in Malaysia? Second, what is the relation between civil society and political change? This discussion found out that civil society is the important contributor for society opinion to create the state change and direct to open. This is because civil society is an institution which has the power to fight, refute, and criticize the state authoritarian action to society.
\end{abstract}

\begin{abstract}
Abstrak
Artikel ini membahas tentang gerakan masyarakat sipil di Malaysia. Perbincangan tersebut penting karena dua sebab. Pertama, masyarakat sipil lahir karena menuntut perubahan politik ke arah keterbukaan yang berkeadilan. Gerakan ini lah yang menjadi pondasi lahirnya protes masyarakat terhadap pemerintah yang berkuasa. Atas dasar ini juga, satu pertanyaan mucul dalam perbincangan artikel ini, apa yang dimaksud dengan masyarakat sipil? Dan bagaimana sejarah kemunculannya di Malaysia? Kedua, apa hubungannya masyarakat sipil dengan perubahan politik? Hujah artikel ini mendapati masyarakat sipil adalah penyumbang penting bagi terbentuknya opini masyarakat bagi terciptanya perubahan negara ke arah yang lebih terbuka. Ini karena mereka memiliki kemampuan untuk melawan, membantah dan mengkritik sikap otoriter negara terhadap masyarakat.
\end{abstract}

Kata Kunci: Masyarakat Sipil, Demokrasi, Politik Baru

TAJDID Vol. XV, No. 1, Januari - Juni 2016 | 71 


\section{Pendahuluan}

Analisis mengenai masyarakat sipil memiliki tempat yang khusus dalam ranah demokrasi. Ianya dianggap sebagai ruang publik yang otonom karena menjadi mesin pengerak bagi perubahan rezim otokratik ke rezim yang demokratik. Dalam sejarahnya masyarakat sipil di beberapa negara berhasil menumbangkan kekuasaan otoriter seperti yang berlaku di Filipina 1986, dan Indonesia 1998. ${ }^{1}$ Keadaan

${ }^{1}$ Kemunculan masyarakat sipil di Filipina pada tahun 1986 disebabkan oleh perilaku korup Marcos dan kroni politiknya dalam menjalankan roda pemerintahan. Ini juga disebabkan kebijakan pemerintah yang bersifat terberpusat (over-centralized), dalam setiap kebijakan. Misalnya, pemerintah Marcos mengontrol kebebasan politik, menangkap tokoh oposisi, melarang kebebasan media kecuali yang diizinkan pemerintah, dan menggunakan militer yang represif untuk menekan rakyat. Selain itu, perilaku korup rezim mengakibatakan berlakunya kemunuduran ekonomi sehingga pemerintah terpaksa berhutang ke luar negeri. Kemunduran ekonomi ini, mengakibatkan berlaku pemberontakan oleh kelompok separatis yang menuntut kemerdekaan dari Filipina seperti gerakan Moro National Liberation Front, (MNLF), dan Bangsa Moro Army, (BMA) yang menimbulkan kemarahan rakyat terhadap pemerintahannya. Dari berbagai kesalahan dalam mengelola roda pemerintahan, masyarakat sipil akhirnya melakukan demonstrasi menuntut Marcos mundur dari jabatannya. Sebaliknya, pemerintahan Marcos bersikukuh mempertahankan kekuasaannya dengan menggunakan militer untuk menangkap dan membunuh kelompok demonstran. Tindakan kejam ini tidak menyurutkan gerakan demonstran untuk menuntut perubahan dan bersatu menjatuhkan beliau, mulai dari mahasiswa, kelompok profesional, ahli akademik, elit partai oposisi, pebisnis dan pemimpin gereja bersatu padu menyuarakan perubahan. Untuk perbincangan lanjut, lihat McCoy, (1993), dan Katsiaficas (2012).

Begitujuga yang berlaku di Indonesia, jatuhnya Soeharto pada tahun 1998 dikarenakan sifat pemerintahannya yang terpusat, rezim militer yang otoriter dan perilaku korup pemerintah. Keadaan ini menyulut kemarahan rakyat dan gerakan mahasiswa untuk menuntut Soeharto turun dari jabatannya. Sayangnya, gerakan masyarakat sipil ini, mendapat perlawanan dari rezim militer yang berkuasa dengan menembak mati empat mahasiswa pada 14 Mei di Jakarta. Tindakan tersebut mengakibatkan demonstrasi jalan semakin meluas dan menjadi kerusuhan masa yang juga berlaku penindasan terhadap etnik Cina. Kondisi yang tidak terkendali lagi di Jakarta mengakibatkan TNI berhadapan langsung dengan masyarakat sipil sehingga ramai demonstran yang di tangkap, di culik dan terbunuh oleh TNI. Dalam keadaan yang tertekan, masyarakat sipil dan gerakan mahasiswa tidak berundur ianya malah berhasil menduduki gedung DPR. Pada 21 Mei 1998, Soeharto bersedia mundur dari jabatannya sebagai Presiden Republik Indonesia yang telah berkuasa lebih dari 30 tahun. Untuk perbincangan lanjut, lihat Denny J. Ali (2001) dan Leo Agustino (2010).

\section{2 | TAJDID Vol. XV, No. 1, Januari - Juni 2016}


ini dinilai oleh pakar bahwa kekuatan masyarakat sipil adalah sebagai penyeimbang dan pengontrol kekuasaan. Beberapa faktor yang menyebabkan masyarakat sipil bergerak melawan kekuasaan adalah disebabkan berlakunya penyalahgunaan kuasa oleh elit, kemunduran ekonomi, keterlibatan militer dalam politik, pencabulan hak asasi manusia dan pemerintah yang otoriter. Impak dari gerakan masyarakat sipil ini berhasil melemahkan dominasi kekuasaan dan menjatuhkan rezim yang berkuasa. Melalui gerakan inilah proses pendemokrasian dapat dijalankan di negara yang baru meraih kebebasan politiknya.

Jika seperti ini keadaannya, maka konsep masyarakat sipil sebagai agen perubahan dari sistem yang otokratik ke demokrasi sangat relevan digunakan sebagai pengontrol kekuasaan. Ini karena peran dan kontrol mereka mampu membawa kepada perbaikan ekonomi dan keterbukaan politik. Seperti yang berlaku di Malaysia, masyarakat sipil berhasil memaksa pemerintah membebaskan tahanan politik Anwar Ibrahim, namun gagal mengantikan rezim menjadi demokrasi. Dari perbincangan ini, maka artikel ini membahas hal tersebut dengan memunculkan beberapa pertanyaan seperti; Apa yang dimaksud dengan masyarakat sipil? Apa peran mereka? Dan cara apa yang mereka gunakan untuk melawan rezim yang otokratik? Bagi menjelaskan fenomena ini, maka artikel ini dibahagi ke atas tiga bahagian. Pertama membahas kerangka konseptual masyarakat sipil yang berkaitan erat dengan analisis artikel ini. Kedua, membincangkan kemunculan masyarakat sipil. Dan ketiga menghuraikan kedinamikaan masyarakat sipil. Akhir sekali menyimpulkan perbincangan artikel tersebut.

\section{Definisi Masyarakat Sipil?}

Konsep demokrasi menempatkan masyarakat sipil sebagai bahagian penting dalam proses menuju perubahan politik. Secara umumnya, masyarakat sipil dipahami sebagai individu, organisasi sipil yang bebas dari kooptasi, hegemoni dan korporatisme negara. Masyarakat sipil juga mencangkup semua golongan seperti asosiasi profesional, mahasiswa, media komunikasi independen, serikat pekerja, LSM dan yang lainnya. ${ }^{2}$ Dalam banyak hal masyarakat sipil

${ }^{2}$ Dalam sejarahnya, konsep masyarakat sipil berkembang dalam tradisi pemikiran politik Barat iaitu dari pemikiran ahli filsafat, Heraclitus (500 SM). Beliau merupakan orang pertama yang memperkenalkan peran masyarakat sipil

TAJDID Vol. XV, No. 1, Januari - Juni 2016 73 
dianggap sebagai media bagi transformasi politik. Ini kerana masyarakat sipil bukan hanya diartikan sebagai ikatan sosial di luar organisasi resmi yang mampu menggalang solidaritas kemanusiaan bagi menciptakan kebaikan bersama yang bersifat universal. Tetapi ianya juga, menjadi kekuatan bagi penyeimbang pemerintah untuk menghalangi penyalahgunaan kekuasaan (Backman 1992:15). Artinya, masyarakat sipil adalah wilayah sosial yang memiliki wilayah otonomi yang berlandaskan persamaan. Menurut Bryant (1995:153) dalam tulisannya Civic nation, civil society, civic religion, masyarakat sipil adalah agen demokrasi yang membawa perubahan dari sistem yang otokratik menjadi demokratik. Ini karena lahirnya negara yang demokratik sangat dipengaruhi oleh peran masyarakat sipil yang aktif dalam menjaga kualitas badan kehakiman, pemerkasaan parti politik, pembelaan hak rakyat miskin dan yang lainnya.

Pandangan Bryant juga didukung oleh pendapat Baker (2002) yang menyatakan bahawa jika tidak ada kelompok masyarakat sipil yang berperan dalam sebuah negara, maka berlaku kemunduran dalam prinsip demokrasi dan hilangnya kebebasan masyarakat itu sendiri. Ini karena masyarakat sipil bukan hanya berperan sebagai kelompok penyeimbang kekuasaan, ianya juga menjadi pengerak bagi partisipasi politik masyarakat yang membawa kepada kesadaran politik masyarakat sehingga mampu menilai perilaku pemerintah yang berkuasa. Oleh itu, jika berlaku penyelewengan kekuasaan seperti ketidak adilan, korupsi, nepotisme dan penyelewengan undangundang, maka masyarakat sipil beserta masyarakat umum bisa

dalam kehidupan bernegara dan bermasyarakat. Dalam pemahaman beliau, untuk mencari arti masyarakat sipil, beliau membahas hukum ketuhanan (devine law) yang berkaitan dengan hak asasi manusia. Kemudiannya pemikiran beliau dikembangkan oleh Plato (427-347 SM), Aristotle (384-332 SM), Cicero (106-43 SM) dan St. Thomas Aquinas (1227-1274). Dari kesemua pemikir ini, St. Thomas Aquinas lah orang pertama yang menggunakan istilah civil society (atau societas civilis dalam bahasa Latin) dalam bukunya Summa Theologiae. Societas civilis yang dimaksudkan oleh St. Thomas Aquinas adalah masyarakat sipil sebagai masyarakat politik yang memiliki aturan hukum tertentu bagi mengatur pergaulan hidup antara individu dalam sebuah masyarakat negara-kota (polis ialah istilah Latin untuk city-state). Dalam kehidupan kota, warga masyarakat hidup di bawah hukum sipil sebagai dasar yang mengatur kehidupan bersama. Beliau membahagikan hukum masyarakat sipil dalam empat kategori, pertama, lex aeterna, kedua, lex naturalis, ketiga, lex positiva dan keempat, lex divina, kesemua hukum ini memiliki kaitan dengan peran masyarakat sipil. Untuk pembahasan lebih lanjut, lihat Miller (2002), dan Scalet \& Schmidtz (2002). 
melakukan bantahan atas ketidak puasan hati mereka. Hal ini sesuai dengan pandangan Diamon (1999) yang menulis:

"That civil society plays a key role in democratic transition and consolidation by "providing the basis for the limitation of state power, supplementing the role of parties in stimulating political participation, increasing the political efficacy and skill of democratic citizens, educating the masses in democracy, structuring multiple channels, beyond the political party, for articulating, aggregating, and representing interests, empowering the powerless to advance their interests, generating a wide range of interests that may crosscut, and so mitigate the principle polarities of political conflict, recruiting and training new political leaders, developing techniques for conflict mediation and resolution, giving citizens respect for state and positive engagement with it, and facilitating the spread of ideas essential to the achievement of economic reform" (Diamond, 1999: 239-250)."

Padangan Diamon ini sangat optimis dalam melihat peran masyarakat sipil sebagai agen perubahan. Namun, mendapat bantahan dari Gupta (2001:307) yang menyatakan masyarakat sipil di Barat berbeda dengan di Asia. Beliau mencontohkan India, masyarakat sipil lahir karena diskriminasi negara dalam pengagihan ekonomi masyarakat dan mengabaikan tanggungjawabnya ke atas kesejahteraan kelas bawah sehingga kelas bawah (golongan paria) melakukan pembangkangan terhadap pemerintah. Sederhananya, di India, masyarakat sipil lahir dari kelas bawah, bukan dari kelas menengah dan atas yang menuntut persamaan hak. ${ }^{3}$ Dari aspek ini, apabila negara mendominasi, menghegemoni dan mengatur kehidupan

${ }^{3}$ Setelah India mendapat kemerdekaan dari penjajahan British pada 15 Agustus 1947, India menyusun perlembagaan negara mereka. Dalam penyusunan perlembagaan ini ditetapkan bahwa sistem kasta tetap digunakan dalam pemerintah India yang bertujuan membedakan kelas masyarakat. Sistem kasta menentukan banyak hal dalam kehidupan bermasyarakat, seperti pekerjaan, tingkat kesucian rohani dan kelas sosial. Ada empat kasta di India iaitu Brahmana, Kesatria, Waisya dan Sudra. Kasta Brahmana adalah yang disandang para rohaniawan, Kesatria untuk orang pemerintahan, Waisya untuk para petani dan nelayan serta Sudra disandang oleh golongan pelayan. Golongan kasta paling bawah sering dipandang sebelah mata karena dianggap mengotori kesucian orang lain dan terlahir untuk dieksploitasi. Ada juga kaum Paria, golongan orang rendahan yang melayani para Brahmana. Kaum ini hanya diperbolehkan kerja disektor pelayanan seperti penjaga toilet dan pengangkut sampah. Untuk perbincangan lebih lanjut, lihat Gupta (2001) dan Vohra (2014).

TAJDID Vol. XV, No. 1, Januari - Juni 2016|75 
individu, maka masyarakat sipil akan bertindak untuk menghalang tindakan negara tersebut dengan tujuan mencegah wujudnya pemerintahan yang otokratik (Gellner 1994:115). Oleh itu, ruang masyarakat sipil harus tetap terbuka untuk berinteraksi dengan pemerintah, memunculkan berbagai wacana kritikal yang objektif dan rasional. Jika negara tidak dapat memberikan kebebasan bagi masyarakat sipil, maka berlaku pembangkangan oleh masyarakat. Pendapat senada juga dihujahkan oleh Bedau (1991) yang mengkaji tentang pembangkangan masyarakat sipil atau Civil Disobedience, iaitu:

"A host of informal group activities and meeting places that connect individuals, build trust, encourage reciprocity, and facilitate exchange of views on matters of public concern. In order for the notion of civil society to make sense, it must involve some structuring of relations that distinguish it from society itself-the relationship to the state provides this structuring principle. Civil society is situated in the rules and transactions that connect state and society." (Bedau 1991:174).

Jika merujuk dari definisi Bedau artinya setiap elemen masyarakat sipil harus lah bebas dari campurtangan negara dan negara tidak mengontorol apalagi menghegemoni. Tetapi sebaliknya masyarakat sipil dan negara harus saling bekerjasama untuk menuju perubahan yang lebih baik. Kerjasama ini juga bertujuan untuk menghindari berlakunya pembangkangan masyarakat sipil terhadap negara yang dapat membawa kepada perpecahan. ${ }^{4}$ Dengan arah yang tidak berlawanan, Chandhoke, menambahkan bahwa masyarakat sipil merupakan: "... the site at which society enter into relationship with the state (Chandhoke 1995:12)." Jika aspek ini, tidak mampu diberikan oleh negara maka berlaku keadaan yang sebaliknya. Misalnya di Tunisia, masyarakat sipil bangkit melawan karena tindakan otoriter Presiden Zine El Abidine Ben Ali yang telah memerintah selama 23 tahun.

${ }^{4}$ Pembangkangan sipil pernah terjadi di Eropa Timur pada tahun 1980-an yang disebabkan oleh dominasi negara terhadapa rakyat dan sifat pemerintah yang otoriter. Keadaan ini berlaku karena dinafinya penglibatan masyarakat dalam politik dan matinya demokrasi. Oleh itu, gerakan sipil bergerak melawan pemerintah yang berkuasa sehingga berimpak kepada proses pendemokrasian. Kesempatan ini juga dimanfaatkan oleh rakyat Kesatuan Soviet untuk melakukan pembangkangan sipil yang memberi kesan terhadap jatuhnya rejim komunis di negara tersebut. Pembangkangan semakin meluas impaknya yang membawa efek domino di banyak negara Eropa Timur. Untuk penjelasan lanjut, Franco (2001) dan O’Rourke (2002).

76 | TAJDID Vol. XV, No. 1, Januari - Juni 2016 
Pemerintahan otoriter ini menyebabkan tumbuh suburnya perilaku korup dalam pemerintah yang berimpak terhadap kemunduran ekonomi negara, pengangguran dan kemiskinan. ${ }^{5}$ Ini menunjukkan peran masyarakat sipil tidak dapat dipandang remeh dalam membawa perubahan. Sebab masyarakat sipil dalam arena politik sebagai pengawal aktivitas pemerintah melalui mekanisme checks and balances (pengawasan dan perimbangan) yang membawa pada perubahan rezim.

Huraian definisi dan analisis kasus di atas menunjukkan bahawa masyarakat sipil merupakan satu organisasi yang memiliki keterkaitan yang rapat dengan pemerintah. Ini karena masyarakat sipil merupakan satu konsep otonomi yang terdiri dari aktor-aktor tertentu dalam memperjuangkan hak asasi masyarakat. Untuk mewujudkan kebebasan masyarakat, aktor dalam masyarakat sipil ini berperan mewujudkan suatu pendekatan dan pemahaman politik yang memberi kesadaran rakyat pentingnya memperjuangkan hak-hak dasar mereka sebagai individu atau kelompok yang bebas dari tekanan kekuasaan. Oleh itu, masyarakat sipil sebagai agen perubahan telah memberi kesan terhadap berlakunya perubahan rezim dari otokratik ke demokratik. Di samping itu, masyarakat sipil juga bertindak untuk menghalangi berlakunya dominasi dan hegemoni kekuasaan yang digunakan oleh pemerintah untuk membungkam pembangkangan sipil.

${ }^{5}$ Gerakan masyarakat sipil di Tunisia bermula pada 17 Desember 2010 apabila seorang pemuda berusia 26 tahun lulusan kolej Mohamed Bouazizi membakar diri karena barang dagangannya disita oleh polisi. Kejadian ini menyebabkan beliau dibawa ke rumah sakit dan mendapat perawatan berharihari, namun Bouazizi akhirnya meninggal dunia pada 4 Januari 2011. Kematian beliau telah membangkitkan semangat anak muda untuk melawan rezim Ben Ali yang otokratik. Bouazizi adalah wajah rakyat Tunisia yang menderita. Beliau adalah tiang keluarga dan dia harus membiayai kehidupan ibu dan adiknya. Itu sebabnya, Bouazizi bekerja apa saja, termasuk menjadi penjual sayur dan buah. Kemudian tindakan beliau di ikuti oleh Houcine Neji yang bunuh diri melompat ke tiang pemancang listrik voltan tinggi dan Lotsi Guadri yang bunuh diri dengan menenggelamkan diri ke dalam sumur. Selepas itu, dalam kurun waktu 10 hari, tiga anak muda Tunisia lain, mencoba bunuh diri, karena kemiskinan. Ketiadaan lapangan kerja, dan rakyat hidup dalam politik yang anti kritik (Naori 2013; dan Sonia 2014).

TAJDID Vol. XV, No. 1, Januari - Juni 2016 |77 


\section{Masyarakat Sipil Malaysia: Sejarah Awal Pembangkangan}

Philip (2003) membandingkan gerakan sipil di Malaysia dan Indonesia. Hujahnya mendapati masyarakat sipil di Malaysia samar kemunculanya karena rezim bertindak otoriter dengan menggunakan undang-undang ISA sebagai alat penekan bagi individu dan kelompok yang tidak bersefahaman dengan pemerintah. ${ }^{6}$ Penyalahgunaan akta tersebut menyebabkan berlakunya tindakan semena-mena elit politik sehingga berlaku korupsi, kolusi dan nepotisme. Tindakan inilah mencetus lahirnya organisasi masyarakat sipil progresif di Malaysia.

Meskipun demikian, NGO pertama yang lahir di Malaysia bukanlah NGO yang berorentasi politik. Pada tahun 1969 NGO pertama yang ada adalah Consumers' Association of Penang (CAP) yang didirikan dan dipimpin oleh S.M. Idris di Pulau Pinang. NGO tersebut bergerak di wilayah regional ekonomi Malaysia dan memiliki hubungan luas dengan NGO Internasional dibidang sama seperti Consumers Interntional di Amsterdam. Bahkan semakin berkembangya CPA, S.M. Idris mendirikan satu lagi NGO Sahabat Alam Malaysia (SAM). Dan pada periode 1990 NGO semakin berkembang di Malaysia seperti Tenaganita yang bergerak di bidang hak-hak perempuan, hak asasi manusia (HAKKAM), politik reformasi (HANYA), dan Hak Hindu (HINDRAF) dan banyak lagi.

${ }^{6}$ Akta Keselamatan Dalam Negeri (Internal Security Act, ISA) disahkan sebagai undang-undang pada tahun 1960. Di bawah akta ini, sesiapa pun yang di curigai melakukan tindakan yang mengancam keselamatan negara dapat ditahan oleh polisi selama 60 hari berturut-turut tanpa sebarang pembicaraan. Selama tempoh ini, seseorang yang ditahan di bawah ISA semasa 60 hari pertama tidak dibenarkan berkomunikasi dengan dunia luar. Selain itu, pengacara dan ahli keluarga juga tidak diizinkan mengunjungi orang yang ditahan. Setelah 60 hari, seorang tahanan boleh ditahan lagi tanpa bicara selama dua tahun oleh Menteri Hal Ehwal Dalam Negeri yang memiliki kekuasaan mutlak menangkap seseorang jika masih dianggap sebagai ancaman tanpa perlu merujuk kepada mahkamah. Penggunaan ISA ini, kebanyakannya digunakan untuk menangkap ahli politik yang membangkang pemerintah sehingga tujuan ISA melenceng dari hakikatnya untuk menahan penganas yang mengancam keselamatan negara. Di antara ahli politik yang ditahan di bawah ISA adalah Lim Kit Siang, Karpal Singh, Lim Guan Eng dan Anwar Ibrahim. Tindakan inilah yang mengakibatkan muncul bantahan dari dari masyarakat sipil, ahli politik dan NGO untuk mencabut undang-undang ISA di Malaysia (Mauzy 1993:44). 
Berkembangnya NGO memberi dampak kepada keberanian media untuk menerbitkan berita kritis yang mengkritik pemerintah seperti Utusan Consumer mencetak 80,000 koran dalam bahasa Inggris, Cina, dan Melayu. Kebelakang terjadi ledakan aktivis internet dan bloging di Malaysia yang aktornya adalah aktivis dari hak asasi manusia iaitu Raja Petra Kamarudin. Di sini, dapat dilihat pemetaan perkemabangan masyarakat sipil di Malaysia dalam berbagai peristiwa dan kerjasama antar komunitas semakin merancakkan dinamika perpolitikan. Bahkan penangkapan Anwar Ibrahim menjadi bahagian sejarah politik di Malaysia karena melalui penangkapan tersebut muncul oposisi kuat yang mengabungkan semua elemen masyarakat berbilang etnik ke dalam satu naungan partai politik iaitu Partai Keadilan Rakyat.

Kemunculan Partai Keadilan Rakyat dalam pergolakan politik menjadi alternatif terkontruksinya kepolitikan oposisi. Menariknya, Partai Keadilan Rakyat merupakan satu penggabungan dari beberapa organisasi yang pro terhadap demokrasi. Gerakan untuk keadilan sosial (ADIL) yang diilhami paradigma perjuangan, menjadi organisasi payung bagi organisasi yang lainnya. Melalui ADIL kampanye tetang reformasi politik, ekonomi, dan sosial semakin gencar disuarakan, agenda yang ditawarkan oleh ADIL disambut riang gembira oleh para aktivis yang memiliki perbedaan latar belakang politik, kelas, dan etnik. Keberhasilan ADIL menarik para aktivis akhirnya terkontruksi satu wadah partai iaitu Partai Keadilan. Tidak lama ditubuhkan Partai Keadilan pada bulan April 1999, Wan Azizah Wan Ismail melakukan konsolidasi dengan pucuk pimpinan Partai Rakyat Malaysia yang melahirkan kesepakatan pengabungan dua partai dengan nama Partai Keadilan Rakyat. Dan menarik jajaran pimpinan NGO terkemuka seperti Iren Fernandez (Tenaganita), Tien Chua (Gagasan) dan Chandra Muzaffar (Singkat) ke dalam jajaran pengurus.

Bergabungnya beberapa pimpinan NGO ke dalam Partai Keadilan Rakyat merupakan bentuk protes terhadap penzoliman hak asasi (Anwar Ibrahim). Chanra Muzaffar mengemukakan alasanya bergabung dengan PKR karena kasus Anwar dibuat atas rekayasa politik, peran NGO tidak cukup untuk mengontrol negara yang semakin semena-mena menggunakan kekuasaan dan telah menghancurkan lembaga penting seperti pengadilan. Apa yang diuapayakan oleh Chandra Muzaffar membangkitkan kesadaran politik masyarakat Malaysia. Misalnya, gerakan masyarakat sipil yang

TAJDID vol. XV, No. 1, Januari - Juni 2016 | 79 
dilakukan oleh kelompok HINDRAF (gabungan dari semua NGO hindu Malaysia), menentang pengucilan terhadap kebebasan beragama, semangat saling menghargai antar agama menjadikan masyarakat menyatu sebagai satu kesatuan bangsa yang mengkritik kebijakan pemerintah. Bergeraknya rakyat sipil di Malaysia dapat difahami sebagai penyebaran idea demokrasi. Indonesia contohnya, melalui penyatuan gerakan mahasiswa, NGO dan masyarakat sipil, idea demokrasi menyebar luas keseluruh lapisan masyarakat dan menolak gagasan politik yang ditawarkan oleh rezim berkuasa. Penyebaran idea ini pada gilirannya merefleksi apa yang disebut Eyermen \& Jamison (1999) sebagai kepentingan pengetahuan generasi tertentu untuk masa mendatang. Dalam arti lain, pengetahuan generasi tertentu ini lah yang melahirkan perjuangan dan gerakan untuk melakukan perubahan. Dapat dikatakan penyatuan masyarakat sipil merupakan bentuk daripada pemantapan idea sebuah generasi baru dalam membentuk identitas kolektifnya.

\section{Sebagai Momentum Kelahiran Semula Masyarakat Sipil}

Kedinamikaan masyarakat sipil Malaysia menemukan momentumnya pada tahun 2008 karena saat ini diadakan pemilihan umum ke dua belas. Pemilu tersebut telah menggabungkan kekuatan masyarakat sipil ke dalam wadah partai politik yang tergabung dari Partai Islam Malaysia (Pas), Partai Aksi Demokratik (Dap) dan Partai Keadilan untuk merebut kekuasaan. Melalui wadah partai, masyarakat sipil menentang pemerinrah yang berkuasa dengan berhasilnya memenangi lima provinsi yang cukup berpengaruh dalam ekonomi Malaysia, Kuala Lumpur (Negeri Persekutuan) merupakan Ibu Kota Malaysia, Selangor, mengililingi pusat kota Malaysia, Pulau Pinang, (tempat mayoritas kaum Cina dan sebagai arus perdangangan ekonomi), begitu juga dengan provinsi Kelantan dan Kedah. Meskipun, Barisan Nasional menguasai mayoritas suara diparlemen ianya ditafsirkan sebagai kekalahan simbolis untuk barisan yang menggugah kepemimpinan Perdana Menteri Abdullah Ahmad Badawi (Dori Efendi 2011:44).

Pertanyaannya bagaimana masyarakat sipil bergerak? Zawiyah Mohd Zain dalam desertasinya yang bertajuk 'Ketidakakuran sipil dan impaknya ke atas pendemokrasian di Malaysia' (2013). Mendapati pendemokrasian politik berlaku di Malaysia di sebabkan oleh gerakan

80 | TAJDID Vol. XV, No. 1, Januari - Juni 2016 
sipil yang memainkan peranan dalam politik baru iaitu politik dalam ruangan. Gerakan ini aktif menulis di laman sesawang seperti Blog, FB dan yang lainnya untuk mengkritik pemerintah. ${ }^{7}$ Menurutnya pada tahun 2007, telah terdapat pelbagai blog sama ada blog politik atau lainnya yang mengkritik kepemimpinan Abdullah Ahmad Badawi. Penulis blog ini bukan saja dari kalangan rakyat biasa tetapi mereka merupakan individu yang pernah bersama pemerintah suatu ketika dahulu. Misalnya Blog Dr. Mahathir, mantan Perdana Menteri Malaysia, Kadir Jassin, bekas Ketua Pengarang New Straits Times Press (NSTP) dan juga Ruhainie Ahmad, iaitu bekas Ahli Parlimen. Melalui bangkangan di internet ini juga telah muncul satu gerakan iaitu Perhimpunan Bersih Satu yang diketuai oleh Datuk Ambiga Sreenevasan pada November 2007. Perhimpunan ini telah mendapat sambutan lebih kurang 30,000 orang yang melibatkan pelbagai etnik yang menuntut diadakannya perubahan dalam proses pemilihan umum untuk lebih adil dan terbuka. Antara yang terlibat dalam perhimpunan ini ialah Lim Kit Siang, Hadi Awang, Anwar Ibrahim dan Mohamad Sabu. Tujuan mereka adalah untuk berarak ke Istana Negara bagi menyerahkan memorandum kepada Yang di-Pertuan Agong (YDPA) berkaitan dakwaan bahawa Suruhanjaya Pilihan Raya Malaysia (SPRM) melaksanakan pemilihan umum yang tidak adil dan memihak kepada Barisan Nasonal. (Ooi Kee Beng 2008:11; Johan Saravanamuttu 2008:49; Gatsiounis 2008:59-60).

Masyarakat sipil yang tergabung dalam perhimpunan bersih mebawa empat tuntutan yang harus di rubah oleh pemerintah dalam melaksanakan pemilu. Pertama menyusun kembali daftar pemilih yang ada; kedua, menggunakan tinta permanen dalam proses pemilihan;

${ }^{7}$ Di Malaysia kebebasan media massa dikontrol oleh pemerintah. Media televisi dan media cetak dilarang untuk menerbitkan berita yang sensitif tentang kebijakan pemerintah sehingga masyarakat menggunakan media alternatif untuk menjadi medium bagi mereka mendiskusikan dan mendedahkan kebijakan pemerintah yang tidak populis. Pada tahun 2007 jumlah penggunaan internet di Malaysia sebanyak $47.8 \%$ dari keseluruhan penduduk dibandingkan dengan tahun 1998 iaitu hanya di bawah $15 \%$. Manakala pengguna internet pula pada tahun 1998 hanyalah satu juta berbanding pada tahun 2008 iaitu 14 juta (Internet World Statistics 2009). Apatah lagi pada tahun 2007 fenomena blog dan juga laman sosial sedang melanda dunia internet. Berbanding dengan laman sesawang, Blog dan laman sosial seperti Facebook, Twitter dan Skype adalah lebih mudah dibangunkan di samping dapat berhubung dengan ribuan manusia dengan begitu cepat (James Chin \& Wong Chin Huat 2009:80).

TAJDID vol. XV, No. 1, Januari - Juni 2016| 81 
ketiga, menghapus pemilihan pos; dan keempat, media harus adil dalam meliput kegiatan kampanye semua parti politik. Demonstrasi bersih ini berjalan damai, namun pihak berwenang (polisi) menangkap 17 orang atas tuduhan tidak memiliki izin melakukan demonstrasi. Penangkapan beberapa individu tersebut mencemari nama baik pemerintah yang sedang membangun citra diri pemerintahan rakyat. Ini karena di bawah pemerintahan Abdullah Badawi pemerintah menggunakan pedekatan Islamik dan merakyat untuk membedakannya dengan rezim Dr. Mahathir (Johan Saravanamuttu 2008:49; Gatsiounis 2008:59-60). Meskipun demikian, Perhimpunan Bersih berhasil melakukan perubahan dengan di persetujuinya penggunanaan tinta permanen oleh Komisi Pemilihan Umum (Suruhanjaya Pilihan Raya) dalam pemilu 2008. Sayangnya, keputusan ini ditarik kembali oleh SPR pada saat-saat akhir dilaksanakan pungutan suara atas alasan rentannya berlaku penyelewengan. Menurut Ooi Kee Beng (2008:11) penghapusan ini malah sebaliknya yang terjadi iaitu pemerintah dengan leluasa melakukan kecurangan, sebab tiada bukti bagi seseorang yang telah memberikan suaranya. Sebagai contoh, pada pemilu 2008 banyak ditemukan pemilih hantu, orang-orang yang telah meninggal dunia dan kartu identitas mereka digunakan untuk memilih.

Begitu juga yang dilakukan oleh masyarakat sipil yang tergabung dalam demonstrasi Hindraf pada 25 November 2007. Demontrasi ini memprotes tindakan pemerintah yang mendiskriminasi etnik minoritas Tamil. Tindakan pemerintah yang menghancurkan beberapa kuil mengakibatkan berlaku bantahan jalanan dengan dihadiri 30.000 orang. Demontrasi ini juga disertai oleh kelompok oposisi yang tergabung dalam partai. Akibatnya, gerakan sipil semakin kuat menuntut perubahan. Namun, pemerintah melakukan tindakan represif terhadap beberapa orang pemimpin utama Hindraf atas tuduhan ancaman undang-undang dalam negeri/Internal Security Act (ISA). Diantara yang ditangkap adalah Waythamoorty, Uthayakumar dan V.S Ganapathi (Maznah Mohamad 2008:444).

Dua siri demonstrasi yang dilakukan masyarakat sipil di atas mengakibatkan berlaku ketidak stabilan politik pada era Abdullah Badawi. Ketidak stabilan ini, menyebabkan kepimpinan beliau dinilai lemah dibandingkan dengan pendahulunya Dr. Mahathir Mohammad. Era sebelumnya tidak pernah terjadi demonstrasi besar-besaran di Malaysia, kecuali demonstrasi 1998. Hal ini berimpak terhadap 
kepimpinan beliau yang di desak untuk mundur oleh anggota partainya sendiri sebagai Perdana Menteri dan Ketua Partai. Rakyat juga semakin menunjukkan ketidak puasan mereka terhadap kepimpinan Abdullah Badawi. Selari dengan hujah Diamond (1994:55) yang menyatakan masyarakat sipil ... civil society plays a key role in democratic transition and consolidation by "providing the basis for the limitation of state power, supplementing the role of parties in stimulating political participation, increasing the political efficacy and skill of democratic citizens, educating the masses in democracy, structuring multiple channels, beyond the political party, for articulating, aggregating, and representing interests.

Demonstrasi masyarakat sipil yang berhasil menekan pemerintah tersebut telah menyuburkan gerakan pembangkangan di Malaysia. Pada 2009, berlaku demonstrasi membantah penghapusan ISA tahun 1960. Demontrasi ini berhasil mendesak Perdana Menteri Mohammad Najib Tun Razak mengumumkan penghapusan Akta ISA pada perayaan Hari Malaysia 2011 dengan tujuan menjadikan demokrasi di Malaysia sebagai demokrasi terbaik. Begitu juga dengan gerakan Bersih 2.0 berhasil mendesak pemerintah mengesahkan tuntutan Bersih 1.0 untuk menggunakan tinta permanen sebagai bukti sah pemberian undi dalam pencoblosan. Momentum perubahan yang di bawa oleh gerakan sipil sejak 2007 ini, telah melahirkan kesadaran masyarakat Malaysia untuk membela haknya dari penyalahgunaan kuasa oleh pemerintah.

Persoalannya sejauhmanakah masyarakat sipil berhasil mempengaruhi rakyat? Jika melihat kepada huraian di atas, masyarakat sipil menjadi motor utama menentang kezoliman penguasa. Gerakan masyarakat sipil yang berkesinambungan dalam melakukakan membantah dengan menggunakan berbagai saluran seperti gerakan internet telah menjadi wadah berdemokrasi dengan sifat yang baru. Laman sosial seperti Bloq, $\mathrm{Fb}$ dan yang lainnya dijadikan tempat mendiskusikan kebijakan pemerintah yang berkaitan dengan ekonomi, sosial dan politik. Membongkar berbagai rahasia penting pemerintah yang berkaitan dengan korupsi, kolusi dan nepotisme. Begitu juga, dengan bantahan masyarakat sipil di jalanan, mereka dengan berani menyuarakan kezoliman pemerintah tanpa takut dengan tindakan represif polisi dan undang-undang yang menyekat kebebasan. Hasilnya, berlaku beberapa perubahan dan anjakan politik di Malaysia seperti pemilu 2008, kelompok oposisi memenangi provinsi yang strategis, terciptanya keharmonisan etnik dan agama, penghapusan

TAJDID vol. XV, No. 1, Januari - Juni 2016 | 83 
undang-undang yang menyekat kebebasan dan penggunaan tinta permanen dalam pemilu.

\section{Kesimpulan}

Artikel ini telah menjelaskan tentang gerakan masyarakat sipil dan momentum kebangkitannya di Malaysia. Satu hal penting yang digariskan adalah kebangkitan masyarakat sipil selalu berkait rapat dengan ke tidak adilan rezim dalam menjalankan pemerintahannya. Kasus perhimpunan Bersih menunjukkan realita tersebut. Kegagalan pemerintah untuk melaksanakan pemilu yang jujur dan adil merupakan momentum kebangkitan masyarakat sipil untuk menyuarakan hak mereka. Keadaan ini mudah dipahami dengan cara memahami tindakan pemerintah yang represif dalam menyikapi tuntutan masyarakat. Antaranya adalah penangkapan beberapa orang tokoh penting yang menyertai perhimpunan tersebut. Begitu juga dengan gerakan masyarakat sipil yang tergabung dalam perhimpunan Hindraf. Protes ini menyuarakan penghapusan diskriminasi etnik, agama dan memberikan pelayanan yang baik bagi masyarakat India. Tetapi malangnya pemerintah tetap bertindak represif untuk mematahkan bantahan mereka dengan menangkap tokoh pentingnya.

Meskipun demikian, masyarakat sipil telah memberi impak terhadap penyelengaraan pemilu 2008, dimana kelompok oposisi memenangi lima provinsi yang menguasai ekonomi. Masyarakat sipil juga berhasil menjadi kekuatan penyeimbang pemerintah dengan diikutinya tuntutan mereka untuk penggunaan tinta permanen dalam pemilu. Gerakan ini, telah menyatu dalam satu kelompok oposisi yang kuat, menggunakan internet sebagai wadah demokrasi. Meskipun, masyarakat sipil belum berhasil merubah sistem pemerintah menuju sistem yang demokratik. Tetapi mereka telah menjadi simbol kebangkitan untuk negara yang lebih adil dan terbuka.

\section{Daftar Pustaka}

Beckman, B. Impowerment of Repression: The World Bank and The Politics of African Adjustment. In Authoritarianism, Democracy and Adjustment, eds. P. Gibbon, L. Sachikonye and N. Blade. Uppsala: Some Institute for Advance Study (SIAS), 1992.

Bedau, H.A. Civil Disobedience and Personal Responsibility for Injustice. dalam H.A. Bedau (pnyt.). Civil Disobedience in Focus. London: Routledge, 1991.

84 | TAJDID Vol. XV, No. 1, Januari - Juni 2016 
Bryant, C. Civic Nation, Civil Society, Civil Religion. Cambrigde: Cambridge University Press. 1995.

Case, William. 1993. Malaysia: The Semi-democratic Paradigma. Asian Studies Review 17: 75-82.

Chandhoke, N. State and Civil Society: Exploration in Political Theory. London: Sage Publication, 1995.

Diamond, L. Rethinking Civil Society: Toward Democratic Consolidation. Journal of Democracy 5 (3): 151-169, 1994.

Diamond, L. 1999. Developing Democracy: Toward Consolidation. Baltimore: The John Hopkins University Press.

Dori Efendi. "Perjalanan Demokratisasi Malaysia: Kronologi Singkat." Jurnal Civicus 16 (1), 2005.

Eyermen, R. \& Jamison, A. 1999. Social Movement: a Cognitive Approach. Pennsylvania: Pennsylvania State University Press.

Franco, J.C. Elections and democratization in the Philippines. New York: Routledge, 2001.

Gatsiounis, I. Beyond The Veneer: Malaysia's Struggle for The Dignity and Direction. Singapore: Monsoon, 2008.

Gupta, K. Civil Society: An Inquiry Into the Usefulness of an Historical term. British Journal of Sociology, 44 (3), 2001.

James Chin \& Wong Chin Huat. 2009. "Malaysia's Electoral Upheaval." Journal of Democracy 20(3): 71-85.

Johan Saravanamuttu. A Tectonic Shift in Malaysian Politics. dalam Ooi

Kee Beng, Johan Saravanamuttu \& Lee Hock Guan (pnyt.).

March 8: eclipsing May 13, Singapore: Institute of Southeast Asian Studies, 2008.

Katsiaficas, N.G. Asia's Unknown Uprisings: People Power in the Philippines, Burma, Tibet, China, Taiwan, Bangladesh, Nepal, Thailand, and Indonesia, 1947-2009. Taiwan: PM Press, 2012.

Leo, Agustino. Pendemokrasian di Indonesia: Daripada Orde Baru Kepada Orde Reformasi. Tesis Ph.D. Universiti Kebangsaan Malaysia, 2010.

Loh, K. W. Developmentalism and The Limits of Democratic Discourse. In Democracy in Malaysia: Discourses and practices,

TAJDID vol. XV, No. 1, Januari - Juni 2016 | 85 
eds. K. W. Loh and B. T. Khoo. Richmond, Surrey: Curzon Press, 2002.

Mauzy, D.K. Malay Political Hegemony and Coercive Consociational. dalam J. McGray \& B. O’Leary (pnyt). The Politics of Etnic Conflict Regulation, 106-127. London: Routladge, 1993.

Maznah Mohamad. Malaysia-democracy and The End of Ethnic Politics? Australian Journal of International Affairs 62(4), 2008.

Miller, Jr., F.D. Natural Law, Civil Society and Government. Dlm. B. Rosenblum \& R.C. Post (Pnyt.). Civil Society And Governmnet, 187215. Princeton: Princeton University Press, 2002.

Naori, G. The making of the Tunisian Revolution, Contexts, Architects, Prospects. Edinburgh University Press, 2013.

O'Rourke, K. Reformasi: The Struggle for Power in Post-Soeharto Indonesia. Sydney: Allen \& Unwin, 2002.

Philip, F. Kelly. Developing dissent in industrializing localities: civil society in Penang and Batam. dalam Ariel, Heryanto \& Sumit, K. Mandal (pnyt) Challenging Authoritarianism In Southeast Asia: Comparing Indonesia And Malaysia. RoudledgeCurzon: London And New York, 2003.

Saravanamuttu, J. Malaysian Civil Society-Awakenings? in Risking Malaysia: Culture, Politics and Identity, eds. Maznah Mohamad and S. K. Wong. Bangi: Penerbit Universiti Kebangsaan Malaysia, 2001.

Scalet, S. \& Schmidtz, D. State, Civil Society, And Classical Liberalism. dalam B. Rosenblum \& R.C. Post (Pnyt.). Civil Society And Governmnet. Princeton: Princeton University Press, 2002.

Vohra, R. The Making of India: A Political History. New York: Routledge, 2014.

Weiss, M. and Saliha Hassan. Social Movement in Malaysia: From Moral Communities to NGOs. London: Routledge, 2003.

Zawizah Mohd Zain. Ketidakakuran Sipil dan Impaknya ke Atas Pendemokrasian di Malaysia. Tesis Ph.D. Universiti Kebangsaan Malaysia, 2013.

86 | TAJDID vol. XV, No. 1, Januari - Juni 2016 